\title{
Cross-European Perspective in Social Work Education: A Good Blended Learning Model of Practice
}

\author{
Felicia Andrioni \\ Department of Social-Human Sciences, University of Petroșani, Petroșani 332006, Romania; \\ feliciaandrioni@gmail.com; Tel.: +40-0721137299
}

Received: 29 January 2018; Accepted: 10 May 2018; Published: 12 May 2018

check for updates

\begin{abstract}
European social work education needs to be linked to global demands and contemporary social transformations. It must also be elaborated in accordance with the objectives of sustainable development in higher education and the specific needs of students. This article describes a model of good practice in social work education in a European project that used modern learning models tailored to the changing needs of students from six European country partners in the project. The research methodology used qualitative methods, namely the case study, which in turn combined the use of two research methods: the analysis of the project documents and the observation of the formal and informal aspects of the operation and organization of the project. The results of the survey show that learning modalities based on combining different forms of traditional and modern online learning, such as media learning, Internet connection and virtual lectures, lead to new ways of involvement and active participation in the learning process. To conclude, in the social work field, for the first time at the European level, this project brought added value to cross-border education, proving its innovating character. Through this project, pedagogical solutions were created and adapted to the changing needs of students.
\end{abstract}

Keywords: social work education; blended learning; cross-European connection; students

\section{Introduction}

An increased emphasis on the international dimensions of social work education is both necessary and inevitable in our globalized society and especially given our emphasis on sustainability in higher education [1] (p. 176). National and regional variations in the structure and content of social work education have been considered, and global standards have been highlighted.

Sustainability in higher education (SHE) was internationally introduced in 1978 by the United Nations International Environmental Education Programme UNESCO-UNEP. Domestic and international declarations have been released since, closely connected to environment sustainability in academic training [2] (p. 7). In accordance with UNESCO, sustainable development education is intended to help making decisions in favor of the economic, environmental and social future [3]. For this purpose, reform is being conducted within universities by means of training and research.

Academia's sustainability may be considered as a dynamic creative process involving diverse stakeholders and as the collaborative creation of a product under continuous change [4] (p. 224). The concept of sustainability seen as a social learning process has received less attention than ideas of sustainability as (pre)determined and totally teachable expert products [5].

Social and higher education sustainability point out the need for lifelong and vocational education to endow people with tools for a fruitful dialogue with their peers [6] (p. 107).

Universities and other higher education institutions train the next generations of citizens and have expertise in all the research domains, in social sciences and in natural sciences, humanities 
and technology. Thus, it is up to them to disseminate environmental awareness and to promote the implementation of environmental ethics in society [7].

European social work education should be adapted to today's requirements and to the students' customized needs.

The strengthening of European social work training may be brought about by new options and new learning modalities by providing new kinds of short-time attendance and web-based globalization of social work. It will also open education opportunities, especially for students unable to benefit from the internationalization of conventional mobility options, as well as for employed part-time adult students.

Sustainability-focused education implies creating a space for social learning. This area includes: space for diversity and minority perspectives, area for new manners of thinking, valuing and doing, area dedicated to alternative development routes, but also for respectful peer debates [8] and differences, space for self-determination and area for contextual differences [9].

This paper examines some of the trends and issues facing the educational component of the social work profession as its European dimension evolves. It placed these trends in correlation with blended learning as a combination of traditional and modern learning, an instructional model that allows lecturers, students and content to be in different locations [10] (p. 43).

The paper provides a picture of future challenges in the internationalization of educational social work programs across the world by using information and communication technology (ICT) methods and especially blended learning, enabling an active link and common learning for social work students and teachers.

The next section of the article sets out some key ideas regarding the Adult Life Long Learning In Social Work Network (ALLISW), the rationale and contextual framework for an innovative project based on the blended learning concept in social work education, whereas Section 3 focuses on the methodological aspects in the evaluative process of the educational project founded on evidence-based practice, where a case study is highlighted based on the project entitled "Cross-European blended learning of part-time students".

\section{Adult Life Long Learning in Social Work Network: A Preliminary Foundation for the Creation of an Innovative Project of Education in Social Work}

Building a lifelong learning network in social work and assistance, based on modern learning technology, was an objective global need. This need was identified by several professors from the field of social work in several European universities based on the need for adaptation and modernization of teaching-learning methods to the contemporary needs of students. Even if initially there were also controversial opinions related to the building of this network due to the fact that in general, many professors manifested a resistance to change in the dynamics of classes and student stimulation with the help of computer and Internet-related instruments, because they preferred the classic teaching methods or because of the general reluctance in front of new technologies, despite these reservations in 2010, a network was created for academic communities in the field of social work that carried out common activities themselves or served those interested in sharing their good practice experiences, information or expertise.

The creation of a new international learning network based on modern technologies had a very important role for the professors in the field of social work and assistance, as they had the opportunity to coordinate international conferences, give specialized lectures, make presentations, manage documents of general interest to heterogeneous classes/groups of students and lastly to create a space of debates and discussions for the members of the international groups of students. The Adult Life Long Learning in the Social Work Network is a transnational educational bridge between social work academia and students.

The Adult Life Long Learning in Social Work Network [11] (ALLISW) is a European network of social work adult education and blended learning, which was established a few years ago and 
coordinated by the University of Jyväskylä, Kokkola University Consortium Chydenius, Finland. I this network, the University of Petrosani, Faculty of Science, Department of Social Work is a partner. Along with Jyväskylä, Kokkola University Consortium Chydenius, Finland, and the University of Petrosani, the ALLISW network also includes the following universities: University of Ljubljana (Slovenia), University of Hradec Kralove (Czech Republic), Mykolas Romeris University (Lithuania), and ISCTE-University Institute of Lisbon (Portugal). The actual goal of ALLISW is to elaborate global learning options for employed adult students, in a way that corresponds to their particular situation.

During its activation period, the ALLISW network added to the common knowledge of the European social work, offering new realistic options for grown-up students who had problems attending conventional mobility programs due to the specific situations of their work and study. The scope of ALLISW is to develop international learning and study options for students active in the labor market and thus adapted to their particular situation. Through common forms of blended learning methods, using classrooms based on virtual connections-Internet, distance learning, joint seminars and shorter practice mutual visits-the aforementioned categories of students can meet their educational needs and also have an ideal framework for study and lifelong learning in social work. The ALLISW network took significant steps in developing the professional education of social work at the MA level, offering adult studies along the concept of life-long-learning. Students already based in working life visit the university alongside their jobs and especially on weekends [11]. This provides specific pedagogical solutions and opens up paths for new approaches to direct practical research. ALLISW will thus contribute to the common European knowledge of social work mainly in the work-and-study situation/life-balance. This will open new realistic options for learning at the European level for adult students, who have difficulties using the conventional student mobility options.

\section{Cross-European Blended Learning of Part-Time Students: Rationale and Contextual Framework}

The project Cross-European Blended Learning of Part-Time Students [12] (CEBLPTS) relies on an educational framework for international blended learning where the content can change from one year to the next [13] (p. 166). The project was initiated by the Adult Life Long Learning in Social Work Network (ALLISW). Thus, between the 1 and 6 December 2013, after the Network meeting and international study week entitled "European social work and the Challenges of poverty", it was decided to identify new innovative solutions based on blended learning for students. We also have in view to develop a project to meet the specific needs and choices of social work students in adult or lifelong education that have not been tackled yet at the European level.

The project was created after the members of the Adult Life Long Learning in Social Work (ALLISW) network identified the real needs and options of the Social Work students and decided to undertake significant steps in the development of a professionalized social work education track offering educational options for adult students in accordance with the concept of lifetime learning and in accordance with the Global Agenda for Social Work. Before the project was drafted, following the discussions of the ALLISW representatives, it was found necessary to create some pedagogical solutions tailored to students' ever-changing needs and the development and optimization of innovative options for direct research in social work practice starting from the idea that some students are professionally active, have a job and that their time is limited for optimal participation in courses, seminars or labs.

In the spring of 2014, the European Association of Schools of Social Work (EASSW) agreed to finance the project "Cross-European Blended Learning of Part-Time Students" [12], which was elaborated by the University of Petroşani in partnership with five other European Universities that are members of the ALLISW network, already mentioned.

The purpose of the project was to enhance European social work training by providing new types of short-time attendance and a web-based internationalization of social work education, particularly for those students who are not able to benefit from the conventional mobility options for 
internationalization and for adult students working part-time [13]. This project aims at establishing a blended learning-based type of common module, which permits active European links and common learning for the students and prepares the teachers to use blended learning for internationalization from partner universities.

This international pilot project opened a new innovative window for cross-border learning in the domain of social work. The innovative character of the project is also generated, undoubtedly, by the grounding of educational activity on modern learning technologies, which increased the quality of the educational process. Innovation represents the solving of technical or organizational problems by adopting modern solutions and new improvements, and the CEBLPTS Project demonstrates that [12]. The project facilitated certain changes, which contributed to the enhancement of lifelong learning for the students enrolled in social work, at the European level. These changes were possible by the use of modern learning technologies, within the project. Among them we may enumerate: the transnational discussion forum; the periodic organization of virtual conferences for distance communication through web cam; the creation of web blogs containing diverse information or documents; the creation of the social network dedicated to the social work community with common activities or interested in the exchange of similar information and interests; video sharing sessions allowing video hosting and uploading video materials on the newly-created website; services for organizational sharing of the social sharing type, the users being able to add the content of lectures (PowerPoint), marks and comments.

This project capitalized on the interests and activities specific to social work, using minimal resources in reaching of these objectives.

In the field of social work, for the first time at the European level, this project brought added value to cross-border education, proving to have an innovating character.

\section{Blended Learning, Key for Contemporary Education}

We may find numerous definitions of blended learning in the contemporary education process. In general, blended learning is described as a structured learning opportunities set, using several teaching or study methods, in the classroom or beyond.

It is difficult to define blended learning; the difficulty arises because no consensus has been reached to agree on an "ultimate" definition [14-16]. Oliver and Trigwell (2003) in their article "Can blended learning be redeemed?' claim that the term blended learning may be seen as redundant and meaningless, because mixing traditional classroom methods with technology is a widespread approach [17].

In the vision of Singh (2003), blended learning originates from the idea that learning is not just a one-time event; on the contrary, it is a continuous process, and blending offers various benefits when compared to the use of any single teaching environment in se [18].

Blended learning seems to be the most logical and natural evolution of our training agenda. It is an opportunity to combine the innovative and technological advances brought about by online learning with the interaction and attendance offered in the best of traditional study. It forwards a sophisticated solution to the development challenges, to the individuals' needs. It may be enhanced by the one-to-one contact with personal coaches [19]. Blended learning is usually regarded as a mix of face-to-face and online delivery methods, with the aim of each adding to the other, as a response to enhancing student learning experiences [20] (p. 271).

Blended learning is described as the convergence of direct contact facilities, characterized by synchronous human interaction, with Information and Communication Technology (ICT), which is text based and asynchronous, and involves people acting independently [21]. Mason and Rennie consider that blended learning involves "other combinations of technologies, locations or pedagogical approaches" [22] (p. 12). Yen and Lee (2011) claim that blended learning mixing the best elements of online and face-to-face education has all the chances to become the predominant teaching model of the future [23] (p. 138). In order to successfully convey blended learning, cross-functional teams need to 
get together. Innovation is highly encouraged, and events and regular cross-disciplinary/functional team meetings are organized. These teams need to include different stakeholders. This has been a thorny issue for the current organizational bodies [19] (p. 101).

The topic of blended eLearning has been defined in a number of different ways within today's organizations and universities. However, for most often, it means a blend of training with some type of online learning activity, despite whatever the mix or "blend" might turn out to be [24].

We need to comprehend the general approaches to blended learning. John Bersin argues that blended learning is "the combination of different training 'media' (technologies, activities, and types of events) to create an optimum training program for a specific audience." The term "blended" comes from the idea that traditional trainer-led teaching is being completed by other electronic formats. In this context, "blended learning" programs use many different forms of e-learning, perhaps complemented with instructor-led training and other live formats [25] (p. 56).

In the field of social work, higher education blended learning constitutes a gateway toward new learning experiences adapted to the continually-changing needs of students. This relatively new learning perspective combining traditional and modern learning must take into account several factors. In this respect, Sewpaul and Jones (2004) considered that the social work educational program does not function in a void and has to take into account the influence of combined cultural, economic, communicational, social, political and psychological global factors [26]. In 2008, Garrison and Vaughan described best practices for blended learning practice in academic education and pointed out the need for a link between the online and face-to-face components in order to provide a really blended learning environment [27]. According to Lorenz (2001), the challenges and contradictions of social work education should be renegotiated and adapted to the permanent contemporary changes, as a challenging step toward success [28].

\section{Materials and Methods}

\subsection{Methodological Aspects in the Evaluative Process of the Educational Project Based on Evidence-Based Practice}

5.1.1. Theoretical Approach: The Relation between the Evaluative Process in Educational Programs and Evidence-Based Practice

The assessment or evaluative processes of programs research is comprised by the processes involved in estimating the impact of the intervention program [29] (p. 183). The evaluative process of programs refers to the use of research methods to answer questions related to social work education programs. In many authors' opinion, program evaluation is often divided into two major categories: formative evaluation and summative evaluation [30-32]. The research efforts, in the evaluative process, which combines theory-based evaluation and evidence-based practice, represents "a new field of endeavor-one from which we are likely to learn much in the coming year" [29] (p. 137). At least provisionally, we can conceive of the implementation at the program level as comprising five inter-connected stages that lead from initial exploration of a potential program by possible users to its adoption and maintenance over time [33]. As we may remark in the theoretical discussion, the evaluation programs constitute a complex process, which determines the need to continue with studies that deepen our awareness of this issue. We can think of a program as based on a theory of practice and on a practice of theory. However, in order to conduct the evaluative process of social education programs, it is necessary to look into the theory-based evaluation. Carvalho and White (2004) considered that through program theory, the evaluators can build the evaluation frame starting from the theoretical issues, methods and models [34]. Cooksy, Gill and Kelly (2001) considered that through program theory, one may identify the key elements of the program and clarify how these elements are planned and connected [35]. The theory-based evaluation must be connected with evidence-based practice because evaluative processes should preferably be founded on the theory-based evaluation and also on the evidence-based practice and, in this way, take into consideration the importance of 
translating research knowledge into routine practice. In the opinion of Fraser, Richman, Galinsky and Day "the uptake of research knowledge into routine practice has been accelerated by the evidence-based practice movement" [29] (p.134).

Evidence-based practice defines a practice decision-making process that guides the making of intervention choices based on practitioner expertise, and client preference [36]. In order to be successful, the educational programs should combine, in a balanced manner, the theoretic elements with the practical approaches employed. Numerous researchers have attempted to illustrate in their studies the importance of using theory in social work education practice as a modality of enhancing the quality of social work practice $[37,38]$. Theory and practice in social work are interdependent. A modern trend in social work is evidence-based practice [39] (p. 265). Evidence-based practice represents the systematic process of utilizing evidence gathered from scientific studies of interventions and programs to guide practice decisions [29] (p. 183).

We intend to evaluate the organization and operation modalities of a social work education project called "Cross-European Blended Learning of Part-Time Students". This project targets social work students and teachers, starting from three perspectives, namely:

- $\quad$ the managerial and administrative perspective proposed by Chelimsky (1978), which aims to improve the results of the program and to identify the most efficient forms of intervention [40].

- the assessment-based theory [34] focused on the evaluative process;

- $\quad$ the evidence-based practice $[29,41,42]$.

\subsubsection{Practical Approach: Research Methodological Design}

This part describes the deployment and outcomes of a European project entitled "Cross-European Blended Learning of Part-Time Students" (CEBLPS) financed by the European Association of Schools of Social Work (EASSW) and implemented by the University of Petrosani (Romania), in partnership with five other European universities [13].

The design of the qualitative research was based on an evaluative process relying on evidencebased practice, finalized with the elaboration of a case study that combined the use of two research methods: the observation of the formal and informal aspects of the project operation and organization and the analysis of documents with reference to: descriptive activity reports, minutes of work teams' meetings and managerial documents.

Research in higher education, in an ideal world, should take into consideration the entire complexity of the field. The case study methodology is a common and adequate research instrument used in sustainability surveys at universities. The decision to bring forward case studies in publications for a large audience implies that there are people who may actually learn something from the case study [43] (p. 229). Case studies may offer ideas, suggestions or concepts that may urge outsiders to think about problems they may have never considered, especially related to the institutional change process. The conclusions to be drawn from the case studies presented in the practical approach will depend in part on the reader's background and experience. A study brings about more changes when it challenges the reader and constitutes equal challenges for the author [4]. The development of sustainability in higher education exhibits personal and shared elements. In Yin's opinion, a case study “... investigates a contemporary phenomenon within its real-life context; when the boundaries between the phenomenon and context are not clearly evident; and in which multiple sources of evidence are used" [44] (p. 23). Yin explains that case studies offer the researcher the opportunity to forward the multiplicity of factors having interacted to produce the single character of the entity subjected to the survey [44] (p. 82). It is a method of learning about a complex matter through description and contextual analysis. The result is a description and a theory about why the fact occurred as it did and what may be important to study in similar situations. The case study methodology seems a very adequate research tool for investigating sustainability in higher education [44] (p. 230). 
The research methodology used qualitative methods: the case study, which combined the use of two research methods: the analysis of the project documents and the observation of the formal and informal aspects of the operation and organization of the project. The evaluation of the project was a process that relied on evidence-based practice using the two models of Unrau, Gabor and Grinnell [45] and the model of Fixsen and colleagues [33].

For our analysis, starting from the two models presented before, we structured, within the case study, four steps of the assessment process of the project relying on the conclusive evidence of the project.

\section{Results}

\section{Case Study "Cross-European Blended Learning of Part-Time Students": A Good Practice Pattern}

The case study involved the collection, analysis and interpretation of certain pieces of information related to the objectives, activities, resources and results of the educational program. A social work education program represents a set of activities designed to reach specific objectives and can be used to produce changes at any system level. Any educational program is complex and structured along several stages of action, which include the initiation, planning, implementation, monitoring and, last, but not least, evaluation $[30,46,47]$.

The assessment of an educational program represents the modality of measuring the results attained or to prove the efficiency of the activities carried out, by means of analysis and verification of the way social programs are put into practice.

The purpose of the research aimed at assessing the modality of six organizations and the operations of the project entitled "Cross-European Blended Learning of Part-Time Students".

By means of these research methods, we aim to answer the following research questions:

(1) How can we describe the operation of the educational project?

(2) What were the main activities and results of the program?

For the objective recording of the data collected within the study, we used a reference system focused on the following indicators of the evaluation of project evidence:

(1) number of stakeholders involved in the project activities;

(2) category of activities provided within the project;

(3) category of beneficiaries directly and indirectly serviced;

(4) stages specific to the project implementation;

(5) specificity of blended learning offered within the project;

(6) value added of the project results.

In this stage, we finalized the research and elaborated its afferent evaluation and analysis report.

Based on these considerations mentioned before, the present case study was structured into four parts, using the following analysis criteria monitored in the case study program assessment, as follows: (1) rationale and contextual framework of the project; (1) description of the process of implementation; (2) activities implemented as part of the project; (3) main important results of the activities of the project; and (4) project sustainability. The instrument of the case study included the analysis criteria mentioned before.

The supporting documents studied were the following: descriptive activity reports, minutes of work teams' meetings and managerial documents.

(1) Description of the process of the implementation of the project:

During May 2014-July 2015, the project management process had four managerial phases: 
1. The definition phase of the project. This phase involved the following management activities: identifying and analyzing the problem; assessing the project; setting project goals and objectives; estimating available and needed resources; proposing the preparation to advance the project to the EASSW decision forum.

2. The planning phase of the project activities. This phase was based on the following management activities: defining the strategic management approach; defining project tasks; developing an administrative and managerial toolbox; creating/setting a schedule for completion; scheduling and resource allocation; and project team training.

3. The project execution phase. This involved the following management activities: preparation of project activities; implementation of project activities; supervision and performance monitoring of project activities; and development of reports and activity sheets for the phases of the project.

4. The concluding phase of the project. This assumed management of the following activities: completion of commitments related to the project; the final evaluation of the project; achieving the final narrative and financial report; assessing the usefulness of the project; and disseminating and promoting the results at national and international levels.

The project manager has delegated the project team to operatively resolve any problems occurring during the development activities. To achieve effective communication, the following means of communication were used within the team: direct communication, communication based on Adobe Connect virtual media and written communication by e-mail. The manager held regular operational meetings where the activities were carried out and problems encountered were discussed and analyzed, as well as the workloads were set for the next period. The proposed methodology for the project implementation phase used management methods that enabled the establishment of each step that was to be undertaken, efficient time management and correlation of actions, thereby controlling the results of actions undertaken and the prevention of organizational dysfunction that could arise during the implementation process. For important decisions during the project design, the team was consulted in order to choose the most effective decision making options in the project. In the risk management phase, one took into account the approach and planning of the project risk management activities gradually following: (a) risk identification (to prevent any unexpected problems, potential risks have been identified for each activity); (b) quantitative and qualitative risk analysis (analyzed the probability of each risk identified in the preceding process and its impact on project objectives); (c) risk response planning (possible action strategies that took into account two analytical directions: exploiting opportunities; and reducing threats); (d) monitoring and controlling risks.

Planned strategies to address risks were focused on reducing the risk probability and impact, drawing up concrete action plans where risks would materialize and on monitoring the permanent risk. Regarding risk monitoring and control, project monitoring was a continuous process following the execution phases of the project and the manner in which it was conducted. Analysis of project performance involved the collection and dissemination of information concerning project performance. This included the project analysis overview - project situation, in terms of cost and time planning; analysis of evolution-which was conducted by the project team as a percentage of completion; and forecasting the project status or progress in the future.

The review process focused on the monitoring of performance indicators and analyzed performance potential for misconduct. The result of this process materialized in the project files and documents that illustrate achievement indicators of the project. The main work tools used in the project were: activities and the project time table; results of the project; Gantt chart; agendas; virtual meetings; and participant lists.

Regarding internal evaluation (measurement of project status), there was a continuous process of systematic collection and analysis of information on project activities. The internal evaluation plan included information about the project and how that was assessed, the extent to which the objectives were achieved and the expected results obtained. This operation compared periodic steps taken chronologically. The assessment was based on a plan of judgment on progress towards fulfilling the 
objectives. This plan focused on four main issues: resources allocated; activities performed; results obtained; benefits achieved.

Internal evaluation sessions were concretized in progress analysis performance. Analysis sessions highlighted project budget framing and time deviations and identified cost, time and causes that led to these violations. Progress meetings were designed to analyze and eliminate problems and identify possible solutions to compensate for delays.

(2) The activities implemented as part of the project:

The main important activities of the project were: project initiation, registration of the students and teachers of the partner universities, decisions concerning the IT-facilities, first virtual meeting, planning of pre-tasks and presentation of them in the platform and the joint planning process of the course in sessions via the Internet with teachers and students. Students' development and performance of the pre-tasks in cross-country virtual groups involved: practice analysis of a topic and reading-circle; preparing and creating training module entitled "International Social Work and Global Agenda-A bridge between Academia, Professionals and Students"; preparing the international joint learning week entitled "Application of the Global Agenda of Social Work in Education" and a signed bilateral Erasmus agreement between partner universities; joint learning week with presence or virtual participation; further development and reporting of the learning experiences of students and teachers; presentation of the project and its outcomes at the EASSW Conference; further application and dissemination in the practice.

(3) The main important results of the activities of the project:

The most relevant outcomes of the project are: (a) equality in the globalization of social work education; (b) adequate competences in the use of blended learning methods; (c) new European framework of the learning module; (d) web-based study material through the development of a new Erasmus Covenant. The contribution and outcomes of the project were based on the following aspects: equality in the internationalization of social work education through active participation and international experience of those social work students who have few options to use conventional forms; improved skills in using blended learning methods and IT-technology in social work teaching and learning; a new European frame of Learning Module (5 ECTS) based on IT-technology and blended learning, which we can use with varying topics; Internet-based learning material on the "Application of the Global Agenda of Social Work" from various countries produced by the experiences of adult part-time students; development of an Erasmus Agreement between partner universities.

(4) Regarding project sustainability after the implementation of project activities, based on the initial estimate of the project, the following elements have been identified to ensure its sustainability: (a) all deliverables initially included in the request for funding have been achieved, which generated a functional partnership network; (b) the defined structures continue to operate in the project after its completion, providing intrinsic and extrinsic benefits to the project beneficiaries; (c) it is hoped that both the ways of action and the partnership model proposed in the project, once proven viable and made known to other organizations and institutions, will be adopted and put into practice by other actors, as well, both at the national and international level, leading to the development of pedagogical solutions tailored to meet the demands of a changing contemporary world.

Regarding the achievement of the project purpose and for highlighted specific results, I used a reference system focused on the following indicators of the evaluation of the project evidence (Table 1). 
Table 1. The specific results of the project.

\begin{tabular}{|c|c|}
\hline Indicators & Results \\
\hline $\begin{array}{l}\text { (1) number of } \\
\text { stakeholders involved in } \\
\text { the project activities }\end{array}$ & $\begin{array}{l}\text { - } 85 \text { participants from which: } \\
\text { - } 11 \text { social work academic teachers (4 from Petroşani University, Romania, } 2 \text { from } \\
\text { University of Jyväskylä, Finland, } 1 \text { from University of Ljubljana, Slovenia, } 1 \text { from } \\
\text { Mykolas Romeris University, Lithuania, } 1 \text { from University of Hradek Kralove, Czech } \\
\text { Republic, } 2 \text { from University of Lisbon, Portugal (virtual presentation)); } \\
\text { - } 64 \text { students from which: } \\
\text { - } 43 \text { were from Petroşani University, Romania, } 16 \text { from Moldavia, } 2 \text { from University of } \\
\text { Jyväskylä, Finland, } 1 \text { from University of Ljubljana, Slovenia, } 1 \text { from Mykolas Romeris } \\
\text { University, Lithuania, } 1 \text { from University of Hradek Kralove, Czech Republic; } \\
\text { - } 5 \text { social workers and } 5 \text { stakeholders from Jiu Valley, Hunedoara county; } \\
\text { - } 6 \text { social work schools from different countries were active involved in the project }\end{array}$ \\
\hline
\end{tabular}

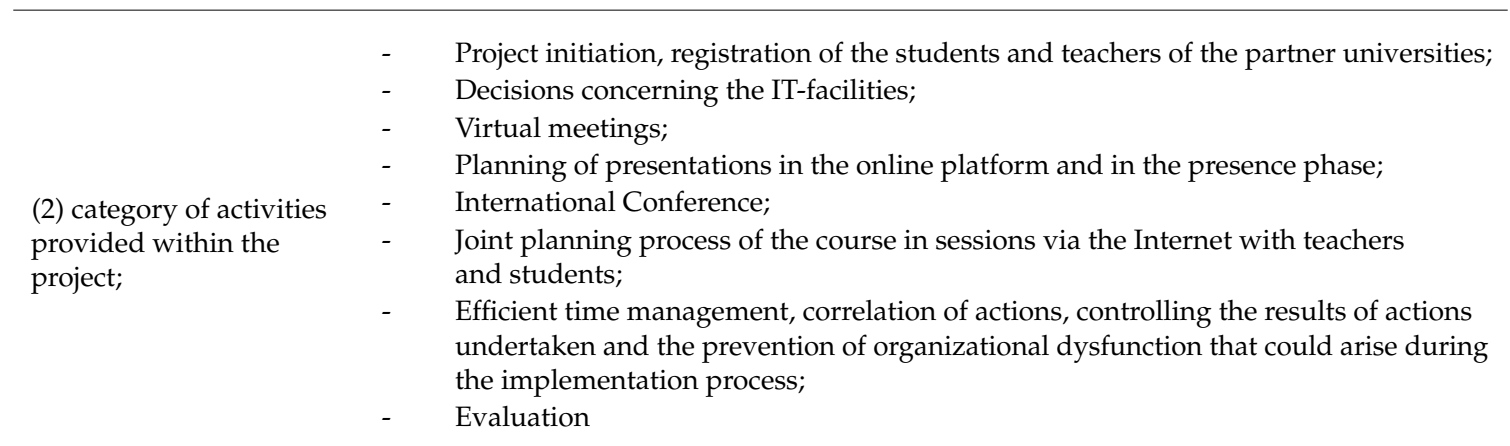

(3) specificity of blended learning offered within the project
Communication based on Adobe Connect virtual media and written communication by e-mail;

- $\quad$ Enhanced competences in using blended learning methods;

- New European framework of the learning module
(4) the learning content for international students
- $\quad$ Students' development and performance of the pre-tasks in cross-country virtual groups: practice analysis of a topic and reading-circle;

- $\quad$ Preparing and creating training module entitled "International Social Work and Global Agenda-A bridge between Academia, Professionals and Students";

- Preparing international joint learning week entitled "Application of the Global Agenda of Social Work in Education";

- Joint learning week with physical presence or virtual participation with many topics: promoting multiculturalism in social work education, practice and research: examples and critical analysis (Lithuania); education and intervention with homeless people in social work (Portuguese experience); McDonaldization of social work in the public administration of social affairs in the Czech Republic; perspectives of communication, communities and citizenship (Romania); activities of social workers assisting social risk families to satisfy the needs of their children (Lithuania); the global agenda and contemporary tendencies in social work (Romania); forced migration as a concept and phenomenon (Finland);

- $\quad$ Further development and reporting of the learning experiences of students and teachers

In addition to the presentations, the partners of the project agreed to create a joint international training course entitled "Social work in an international context". There are five new course credits for students in master's degree programs in combined form, as well as students on Erasmus mobility + (based on the Erasmus Mobility Agreement between the partner universities). The course is based on e-learning technology. The course had six topics, each provided by a different partner university. The teaching theme will ensure 45-min periods of recorded lecture in English supported by PowerPoint presentations, training materials, references and topical articles. The lessons began in the 2016 summer semester, and other universities could also become partners in this training frame. 
Regarding experiences from the participants, the students received information about the meetings and presented their aims and content during a plenary session. They seemed really surprised at this introduction and the information about the global agenda.

During the international meeting, participants were involved in the discussion about presentations, challenges and opportunities in the social work field and the evaluation of the project process based on qualitative feedback after each day, where each participant offered verbal feedback regarding the meeting/sessions (see Table 2).

Table 2. The feedback of the meeting participants.

\begin{tabular}{ll}
\hline Participants Feedback (Synthesis) & $\begin{array}{l}\text { The Number of Participants that Agreed } \\
\text { with the Aspects of Discussion Mentioned }\end{array}$ \\
\hline Improvement of knowledge base on a global agenda & 51 from the audience agreed \\
\hline The sessions of the workshop bringing blended learning into reality & 40 participants agreed \\
\hline $\begin{array}{l}\text { Teachers acceptance of the different methods: formal, non-formal } \\
\text { and e-learning }\end{array}$ & 60 participants agreed \\
\hline A challenge particularly active in the online discussion forums & 30 participants agreed \\
\hline $\begin{array}{l}\text { Opportunity to discuss current events in the frame of European } \\
\text { social work education }\end{array}$ & 68 participants agreed \\
\hline
\end{tabular}

The final evaluation of the project was based on the summaries of the participant's discussion groups, which took place at the final conference meeting, on the last day of the meeting, this session of discussions being moderated by the project coordinator. For the final evaluation process, the most important issues debated focused on: the strength and weaknesses of international meetings; suggestions; and future plan for the ALLISW network after the implementation period of the project. The main important positive aspects mentioned by participants (teachers, students, other stakeholders) through the discussion group are seen in Table 3.

Table 3. The strengths and weaknesses of international meetings.

\begin{tabular}{ll}
\hline $\begin{array}{l}\text { The Main Important Positive Aspects Mentioned } \\
\text { by Participants }\end{array}$ & The Negative Aspects Mentioned by Participants \\
\hline different topics of lecturing & $\begin{array}{l}\text { language skills because some students had a basic } \\
\text { level of English }\end{array}$ \\
\hline $\begin{array}{l}\text { blended e-learning process, which allowed a larger } \\
\text { number of participants from other countries }\end{array}$ & some technical difficulties generated by e-connection \\
\hline $\begin{array}{l}\text { diversity of social work approaches } \\
\text { interactive tools that were used during the workshop }\end{array}$ & $\begin{array}{l}\text { large number of hours (on some days) has caused } \\
\text { difficulty in understanding messages }\end{array}$ \\
\hline $\begin{array}{l}\text { contemporary information regarding a global agenda } \\
\text { in social work }\end{array}$ & \\
\hline $\begin{array}{l}\text { better involvement in social work by the students' } \\
\text { team in the organization process }\end{array}$ \\
$\begin{array}{l}\text { future plan/output of the project and exchange of } \\
\text { experiences between participants (multiculturalism) }\end{array}$ \\
\hline
\end{tabular}

\section{Discussion and Limitations}

In order to reach its research objectives, a case study approach was adopted by different authors. In Yin's opinion, a case study is a comprehensive methodology, which incorporates appropriate data collection methods and data analysis techniques [44]. A case study is an intensive study of a specific 
topic, and this method uses different types of data from different sources to have a broad picture of the phenomenon under study.

As regards the limits of the qualitative investigation through the case study combining multiple methods, among the aspects potentially limiting the analysis, we may list: variable efforts of different categories to support the data collection process, some difficulties in the data collection process, restricted area of the investigated activities, selection of analyzed criteria, rather limited for the envisaged issues, and analysis and interpretation of the quality of data obtained, which may be more or less accurate. We should also remark the limits of using a case study approach method, because there is too much information for an easy analysis, which may be difficult to plot in a simple way. It is difficult for researchers to cross-check information when using a case study, and it is difficult to generalize the results in the conventional sense.

Taking into account the recommendations in the field of educational programs assessments, this descriptive type of analysis obviously leaves room for more enhanced analyses and approaches; however, the purpose of the study was to conduct a diagnosis of the educational innovative aspects of blended education offered only within this educational project, not exploring other analytical dimensions or other similar approaches in the domain of social work, because it was a pilot project at the European level in this field.

\section{Conclusions}

In the field of social work, for the first time at the European level, this project brought added value to cross-border education, proving to have an innovating character.

During the project implementation, the network of six universities developed together a frame for a course (module) consisting of various elements of distance-learning, co-operation on the Internet (trialogical learning, social media) and an intensive physical presence week in Petroşani, Romania (where participation also was possible via the Internet), and the presentation of the most important project products by students and teachers was performed at the European Conference of Schools of Social Work in 2015. All these parts have taken place with international co-operation. Students and teachers, which enrolled in this project, worked actively together at an international level via the Internet, through participation in virtual meetings, or other Internet forms of communication, or through participation in the joint learning week in Petroșani (Romania) on 23-27 February 2015 (presence phase). As for the participation in the joint learning week and according to registration desk notes, 85 people participated in the international meeting. Among participants, there were 11 social work academic teachers and 64 students, 5 social workers and 5 stakeholders from Jiu Valley, Hunedoara county. The project provided a base to create an online platform https:/ /www.facebook. com/groups/790064037706857/ to discuss current events in the frame of European social work education and global agenda issues. All participants were able to listen to different topics related to social work education, practice and research.

Through this project, the most important implication for social work education was creating pedagogical solutions adapted to students' changing necessities. This project is based on the points of view expressed by Dziuban, Hartman and Moskal (2004), who think that blended learning should be regarded as a pedagogical approach that mixes the classroom effectiveness and socialization opportunities with the technologically-enhanced active learning possibilities of the online environment, rather than a combination of delivery modalities [48]. Therefore, blended learning is a mix that enhances the interaction between trainer and students, and also among students. In other words, blended learning encourages students to engage in active learning and encourages contact between students and faculty, as well as provides the students with the opportunity to give prompt feedback because blended learning involves online interaction, which may facilitate feedback. Regarding future plans, in conclusion, six European universities in the framework of the international project "Cross-European Blended Learning of Part-Time Students" have agreed to create a joint training course entitled "Social work in an international context". 
The success of this project also showed us how integrating online learning with diverse types of traditional and innovating teaching methods represents the future of education [19].

Networking with the persons who are implementing blended learning can be equally important. Everyone has embarked on a discovery journey; people's willingness to share information is very obvious in the case studies [19] (pp. 128-129).

Acknowledgments: I thank Dana Bates and Monica Roșu for translating.

Conflicts of Interest: The author declares no conflict of interest.

\section{References}

1. Hokenstad, T. The Sage notebook of International Social Work. In Social Work Education; Lyons, K., Hokenstad, T., Pawar, M., Huegler, N., Hall, N., Eds.; Sage: London, UK, 2012; pp. 163-178. ISBN 9780857023339.

2. Wright, T. The Evolution of Sustainability Declarations in Higher Education. In Higher Education and the Challenge of Sustainability, Problematics, Promise, and Practice; Corcoran, P.B., Wals, A.E.J., Eds.; Kluwer Academic Publishers: Dordrecht, The Netherlands, 2004; ISBN 0-306-48515-X.

3. Brito, R.M.; Rodríguez, C.; Aparicio, J.L. Sustainability in Teaching: An Evaluation of University Teachers and Students. Sustainability 2018, 10, 439. [CrossRef]

4. Wals, A.E.J.; Corcoran, P.B. The promise of sustainability in higher education: A synthesis. In Higher Education and the Challenge of Sustainability, Problematics, Promise, and Practice; Corcoran, P.B., Wals, A.E.J., Eds.; Kluwer Academic Publishers: New York, NY, USA; Boston, MA, USA; Dordrecht, The Netherlands; London, UK; Moscow, Russia, 2004; pp. 223-225. ISBN 0-306-48515-X.

5. Wals, A.E.J.; Jickling, B. Sustainability in Higher Education from Doublethink and Newspeak to Critical Thinking and Meaningful Learning. Int. J. Sustain. High. Educ. 2002, 3, 221-232. [CrossRef]

6. Provis, C. Education, Religion, Sustainability, and Dialogue. In Rethinking Work and Learning Adult and Vocational Education; Harris, P.W.R., Lakes, M., Eds.; Springer: Dordrecht, The Netherlands, 2009.

7. CRE-COPERNICUS. CRE-COPERNICUS Declaration; CRE-COPERNICUS Secretariat: Geneva, Switzerland, 1994.

8. Lijmbach, S.; van Arcken, M.M.; Koppen, C.S.A.; Wals, A.E.J. Your View of Nature is Not Mine!: Learning about Pluralism in the Classroom. Environ. Educ. Res. 2002, 8, 121-135. [CrossRef]

9. Olson, E.E.; Eoyang, G.H. Facilitating Organization Change: Lessons from Complexity Science; Jossey-Bass/Pfeiffer: San Francisco, CA, USA, 2001.

10. Williams, N.A.; Bland, W.; Christie, G. Improving student achievement and satisfaction by adopting a blended learning approach to inorganic chemistry. Chem. Educ. Res. Pract. 2008, 9, 43-50. [CrossRef]

11. Adult Life Long Learning in Social Work. A European Network for Social Work as Adult Education and Blended Learning. Available online: http:/ / www.chydenius.fi/en (accessed on 23 April 2017).

12. Andrioni, F. Cross-European Blended Learning for Part-Time Students. Petroșani, Romania. Available online: https:/ / www.upet.ro/evenimente/ (accessed on 23 April 2017).

13. Andrioni, F.; Marica, L.; Turtiainen, K.; Kokkonen, T.; Ferreira, J.; Pena, M.; Sugman Bohinc, L.; Sadauskas, J.; Hlousek, J. Innovative Perspectives in Social Work Education: Cross-European Blended Learning for Part-Time Students; Social Work Education in Europe: Milan, Italy, 2015; towards 2025, Abstract Book; ISBN 9788890975318.

14. Kerres, M.; de Witt, C. A didactical framework for the design of blended learning arrangements. J. Educ. Media 2003, 28, 101-113. [CrossRef]

15. Sharpe, R.; Benfield, G.; Roberts, G.; Francis, R. The Undergraduate Experience of Blended E-learning: A Review of UK Literature and Practice. 2006. Available online: www.heacademy.ac.uk/assets/documents/ research/literature_reviews/blended_elearning_exec_summary_1.pdf (accessed on 17 March 2017).

16. MacDonald, J. Blended Learning and Online Tutoring; Gower: Hampshire, UK, 2006; ISBN 978-0-566-08841-4.

17. Oliver, M.; Tingwell, K. Can Blended Learning Be Redeemed? 2003. Available online: http:/ /www.luispitta. com/mie/Blended_Learning_2005.pdf (accessed on 25 February 2017).

18. Singh, H. Building Effective Blended Learning Programs. Educ. Technol. 2003, 43, 51-54. Available online: http:/ / asianvu.com/bookstoread/framework/blended-learning.pdf (accessed on 1 March 2017).

19. Thorne, K. Blended Learning How to Integrate Online and Traditional Learning; Kogan Page: London, UK, 2003. 
20. Poon, J. Blended Learning: An Institutional Approach for Enhansing Students Learning experiences. J. Online Learn. Teach. 2013, 9, 271-289.

21. Graham, C.R. Blended learning systems: Definition, current trends, and future directions. In Handbook of Blended Learning: Global Perspectives, Local Designs; Bonk, C.J., Graham, C.R., Eds.; Pfeiffer: San Francisco, CA, USA, 2006; pp. 3-21.

22. Mason, R.; Rennie, F. E-Learning: The Key Concepts; Routledge: Abingdon, UK, 2006; ISBN 9780415373074.

23. Yen, J.-C.; Lee, C.-Y. Exploring problem solving patterns and their impact on learning achievement in a blended learning environment. Comput. Educ. 2011, 56, 138-145. [CrossRef]

24. Bielawski, L.; Metcalf, D. Introduction A Time for Blended eLearning. In Blended eLearning Integrating Knowledge, Performance, Support, and Online Learning; HRD Press Inc.: Amherst, MA, USA, 2003; ISBN 0-87425-717-4.

25. Bersin, J. The Blended Learning Book Best Practices, Proven Methodologies, and Lessons Learned; John Wiley \& Sons: Hoboken, NJ, USA, 2004; ISBN 0-7879-7296-7.

26. Sewpaul, V.; Jones, D. Global Standards for social work education and training. Soc. Work Educ. 2004, 23, 493-513. [CrossRef]

27. Garrison, D.R.; Vaughan, N.D. Blended Learning in Higher Education: Framework, Principles, and Guidelines; Jossey-Bass: San Francisco, CA, USA, 2008; ISBN 978-0-7879-8770-1.

28. Lorenz, W. Social work in Europe-Portrait of a diverse professional group. In International Standard Setting of Higher Social Work Education; Hessle, S., Ed.; Stockholm University, Stockholm Studies of Social Work: Stockholm, Sweden, 2001.

29. Fraser, M.W.; Richman, J.M.; Galinsky, M.J.; Day, S.H. Intervention Research. Developing Social Programs; Oxford University Press: New York, NY, USA, 2009; ISBN 978-0195325492.

30. Cojocaru, S.. Apreciative evaluation-A form of formative evaluation. Rev. Res. Soc. Intervent. 2008, 20, $42-48$.

31. Westat, J.F.; Frierson, H.; Hood, S.; Hughes, G.; Katzenmeyer, C. The 2002 User Friendly Handbook for Project Evaluation; The National Science Foundation, Directorate for Education and Human Resources, Division of Research, Evaluation and Communication: Arlington, VA, USA, 2002.

32. Scriven, M. The Methodology of Evaluation; Rand-McNally: Chicago, IL, USA, 1967.

33. Fixsen, D.L.; Naoom, S.F.; Blasé, K.A.; Friedman, R.M.; Wallace, F. Implementation Research: A Synthesis of the Literature; University of South Florida: Tampa, FL, USA, 2005.

34. Carvalho, S.; White, H. Theory-based evaluation: The case of social funds. Am. J. Eval. 2004, 25, 141-160. [CrossRef]

35. Cooksy, L.J.; Gill, P.; Kelly, P.A. The program logic model as an integrative framework for a multimethod evaluation. Eval. Progr. Plan. 2001, 24, 119-128. [CrossRef]

36. Sackett, D.L.; Rosenberg, W.C.; Gray, A.M.; Haynes, R.B.; Richardson, W.S. Evidence based medicine: What it is and what it isn't: It's about integrating individual clinical expertise and the best external evidence. Br. Med. J. 1996, 312, 71-72. [CrossRef]

37. Taylor, C.; White, S. Knowledge, truth and reflexivity. The problem of judgement in social work. J. Soc. Work 2001, 1, 37-59. [CrossRef]

38. Macdonald, G. Effective Intervention for Child Abuse and Neglect an Evidence-Based Approach to Planning and Evaluating Interventions; John Wiley \& Sons Ltd.: Chichester, UK, 2001; ISBN 978-0-471-49147-7.

39. Brăescu, D.P. Evidence based practice in Social Work. J. Soc. Work 2010, IX, 265-273.

40. Chelimsky, E. Differing perspectives of evaluation. In Evaluating Federally Sponsored Programs: New Directions for Program Evaluation; Rentz, C.C., Rentz, R.R., Eds.; Jossey-Bass: San Francisco, CA, USA, 1978; pp. $19-38$.

41. Aarons, G.A. Mental health provider attitudes toward adoption of evidence-based practice: The evidencebased practice attitude scale (EBPAS). Ment. Health Serv. Res. 2004, 6, 61-74. [CrossRef] [PubMed]

42. Haynes, R.B.; Devereaux, P.J.; Guyatt, G.H. Clinical expertise in the era of evidence-based medicine and patient choice. ACP J. Club 2002, 136, A11-A14. [CrossRef] [PubMed]

43. Walker, K.E. The Practice of Sustainability in Higher Education: An Introduction. In Higher Education and the Challenge of Sustainability, Problematics, Promise, and Practice; Corcoran, P.B., Wals, A.E.J., Eds.; Kluwer Academic Publishers: New York, NY, USA; Boston, MA, USA; Dordrecht, The Netherlands; London, UK; Moscow, Russia, 2004; pp. 229-234.

44. Yin, R.K. Case Study Research: Design and Methods; Sage: Beverly Hills, CA, USA, 1989. 
45. Unrau, Y.A.; Gabor, P.A.; Grinnell, R.M., Jr. Evaluation in Social Work: The Art and Science of Practice, 4th ed.; Oxford University Press: New York, NY, USA, 2007; ISBN 0195308069.

46. Popp, L.E.; Cojocaru, M. Management of change. Robot. Manag. 2011, 16, 61-68.

47. Andrioni, F. Management of social work services between theory and practice. Robot. Manag. 2011, 16, 53-57.

48. Dziuban, C.; Hartman, J.; Moskal, P. “Blended Learning” EDUCAUSE. 2004. Available online: http://net. educause.edu/ir/library/pdf/ERB0407.pdf (accessed on 7 March 2017). 